\title{
Severity of chronic asthma
}

\author{
Ann J Woolcock, Daniel Dusser, Isabelle Fajac
}

How is the severity of chronic asthma best assessed and what are the mechanisms that determine its severity? These two questions are difficult to answer because, until we understand what asthma is, it is not possible to describe its severity in a given individual. In the shorter Oxford English Dictionary severity in relation to disease is defined as "violence or acuteness of illness" or "grievousness of affliction". The former definition is useful for exacerbations or attacks. Clinicians have had little difficulty in agreeing on defining the severity of attacks. ${ }^{12}$ The latter definition seems relevant to the severity of the chronic disease which is the subject of these comments. Until recently the severity of asthma was rarely assessed, but with the increasing use of guidelines and drug trials the concept of severity has emerged. The GINA guidelines ${ }^{1}$ classify the disease as intermittent and persistent with severe, moderate, and mild degrees of the persistent disease. There are now a number of scores available to define the severity of asthma ${ }^{3-5}$ based on a combination of symptoms, measurements of airway function, and need for medication.

\section{What determines the severity of asthma?}

It seems likely that asthma results from the presence of both airway inflammation and abnormal behaviour of the airway smooth muscle, and severity-as measured by scores-will be determined by the factors that affect both.

\section{AIRWAY INFLAMMATION}

The gold standard for the severity of airway inflammation is the degree of histological change seen on a biopsy specimen of the airway wall. In theory, the severity is judged in terms of: the number of eosinophils, lymphocytes, the upregulation of Th2-type cytokinins in all layers of the airway wall, the amount of thickening of the wall, the epithelial damage, and the thickness of the basement membrane. Attempts have been made to correlate severity with histological measurements. Cho et $a l^{6}$ showed weak correlations between indices of pathology and response to methacholine; in terms of fatal/non-fatal disease Synek et $a l^{7}$ showed differences between cells, particularly EG2 positive eosinophils, and Roisman et al found a relationship between eosinophilic inflammation and airway response to bradykinin, but not to methacholine. ${ }^{8}$ In spite of these studies the mechanisms by which airway inflammation leads to changes to the dose response curve and to altered airway behaviour are not understood. It is difficult to study this relationship because it is not always possible to take biopsy specimens of the airways. The results of studies to determine the relationship between the number of eosinophils in the sputum, sputum levels of eosinophil cationic protein (ECP), exhaled nitric oxide (NO) and the degree of abnormality on the biopsy specimen will no doubt become available soon.

\section{AIRWAY SMOOTH MUSCLE BEHAVIOUR}

The airway smooth muscle contracts so that the airways narrow too much and too easily causing symptoms. The position and shape of the dose response curve to methacholine or histamine, described as airway hyperresponsiveness, continues to be used as the gold standard to quantify this abnormality. The degree to which peak expiratory flow (PEF) measurements vary during a 24 hour period $^{9}$ can also be used as a rough guide to airway hyperresponsiveness. An increase in spirometric function in response to bronchodilator, whilst it may be diagnostic of asthma, provides little information about the severity of the underlying disease. The resting forced expiratory volume in one second $\left(\mathrm{FEV}_{1}\right)$ or PEF, expressed as a percentage of the predicted value, are recommended in the American guidelines $^{10}$ and in GINA $^{1}$ as one index of severity, but there are no established long term studies of correlations between lung function and biopsy data or with airway hyperresponsiveness. In a patient on treatment spirometric function may be related to the chronicity rather than to the severity of the disease.

The usefulness of the concept of severity lies in the help it gives to understanding aetiology, in comparing populations so that hypotheses about cause can be developed, in deciding initial and long term treatment, and in assessing the effectiveness of treatment strategies. At present the careful and standardised measurement of airway hyperresponsiveness seems to be the single most useful test of severity; however, its constraints must be acknowledged. Airway hyperresponsiveness is not specific for asthma and is only accurate to one doubling dose. Yet, in a given asthmatic individual in whom the baseline $\mathrm{FEV}_{1}$ is known, the shape and position of the dose response curve is usually helpful. Measurement of airway hyperresponsiveness is easily done, comparable between and within subjects, and can be used for all the situations where an index of severity is required.

WHAT ARE THE RISK FACTORS FOR ASTHMA OF DIFFERING SEVERITY?

In spite of the fact that airway hyperresponsiveness can give some idea of severity and measurements of airway hyperresponsiveness and symptoms have been used in many epidemiological studies, ${ }^{112}$ neither the prevalence of asthma in relation to severity nor the risk factors associated with disease of different severity have been published. Studies in Australian children show that the risk factors for asthma are atopy, its early acquisition, the nature of the allergen, parental asthma, and respiratory illness before the age of two years. ${ }^{13}$ Wherever exposure levels to house dust mite (HDM) exist, the strongest risk factor for airway hyperresponsiveness is sensitisation to these allergens. ${ }^{14-16}$ Thus, people in Australia and New Zealand who are allergic to HDM, the mould Alternaria, and cat are at risk from developing persistent disease, whereas those allergic to pollens alone seem to be at little risk of persistent disease. ${ }^{17} 18$

It is widely believed that pollens cause asthma because individuals who are allergic to pollen have their symptoms in the spring, but it is difficult to find evidence from population studies using logistic regression analysis that pollen allergy, in the absence of other allergies, is a risk for the disease. Ragweed is a potent allergen for rhinitis but does not appear to cause chronic asthma. The situation with cockroach allergy is unclear; it is a common allergy in US inner cities yet it appears not to be a risk when formal logistic analysis is undertaken. ${ }^{19}$

In a study of the severity of asthma in patients attending an asthma clinic in Paris the severity measured by airway hyperresponsiveness to methacholine, plus a symptom score, was found to be related to the pattern of skin test 


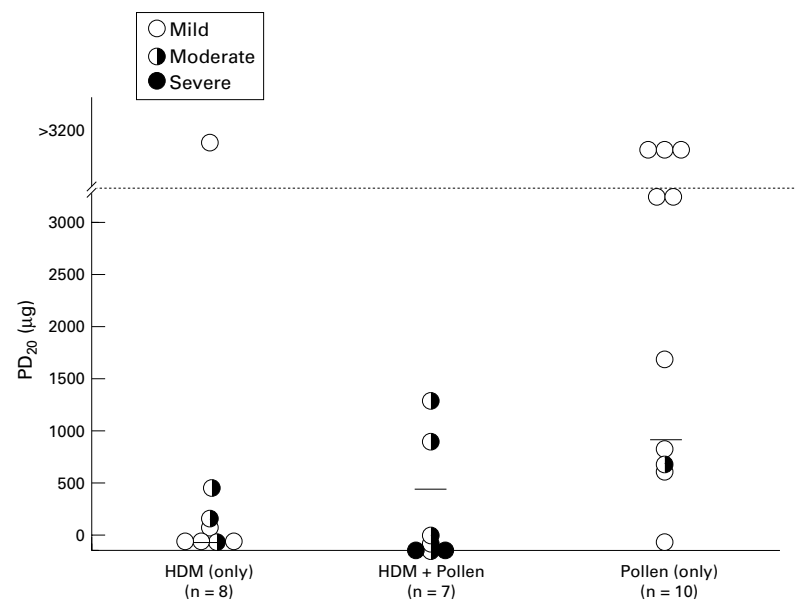

Figure 1 Provocative dose causing a $20 \%$ fall in the forced expiratory volume in one second $\left(P D_{20} F E V V_{1}\right)$ using methacholine in 25 patients attending a clinic for asthma. The patients are grouped according to the groups of allergens to which they were sensitised. HDM = house dust mite.

responses to 14 common aeroallergens. The hypothesis was that people attending the clinic who were allergic only to pollens would have less severe asthma than those allergic to mites and/or other allergens. Airway hyperresponsiveness to methacholine was measured using the method described by Roisman et $a l^{8}{ }^{8}$ and standardised to the method described by Eiser et $a l^{20}$ and a symptom score developed in France called the Asthma Impact Record Index (AIRI). ${ }^{21}$ It was not possible to test the hypothesis vigorously because too few people allergic only to pollens presented at the asthma clinic. The results from this small study of three groups of patients classified according to the groups of allergens to which they were sensitised are shown in fig 1 . Those who did not have a provocative dose causing a $20 \%$ fall in $\mathrm{FEV}_{1}\left(\mathrm{PD}_{20} \mathrm{FEV}_{1}\right)$ were given a value above $3200 \mu \mathrm{g}$, and those not tested because the $\mathrm{FEV}_{1}$ was less than $60 \%$ predicted are shown as filled circles with a $\mathrm{PD}_{20} \mathrm{FEV}_{1}$ close to zero. In the group sensitised only to pollens the $\mathrm{PD}_{20} \mathrm{FEV}_{1}$ was $800 \mu \mathrm{g}$ in all but one patient, whilst in those who were allergic to mites all but one had a $\mathrm{PD}_{20} \mathrm{FEV}_{1}$ of less than $550 \mu \mathrm{g}$. In the group sensitised to both pollen and mites three patients had $\mathrm{FEV}_{1}$ values too low for the test to be performed. All of this group had either moderate or severe asthma as judged by the score. The study showed that, in this population, both the airway hyperresponsiveness and the symptom scores were less in the group allergic only to pollen.

In epidemiological studies in Australia the prevalence of airway hyperresponsiveness in groups of children allergic to pollen, as opposed to HDM, is lower. ${ }^{22}$ In patients with allergic rhinitis airway hyperresponsiveness is often abnormal. In one study the severity of airway hyperresponsiveness was less in patients sensitised to pollens than in those sensitised to HDM alone or with other allergens. ${ }^{23}$ Preliminary results from the European Community Respiratory Health Survey (ECRHS) show that pollen sensitisation is associated with only mild asthma. ${ }^{24}$

It is of further interest that, in the ECRHS, it was found that smoking is associated with an increased risk of sensitisation to HDM, but a decreased risk of sensitisation to pollens. ${ }^{25}$ In Spain Soriano et $a l^{26}$ found, as part of the ECRHS, that sensitisation to timothy grass and olive, as well as to HDM, also correlated with airway hyperresponsiveness, but they did not look at airway hyperresponsiveness in groups who were allergic to specific groups of allergens such as only all pollens, only all mites, etc. Thus, the evidence is mounting that those who develop allergy to pollen antigens are highly likely to get hay fever but are unlikely to get chronic asthma unless they are allergic to other allergens. This may be because pollens are only intermittently inhaled, allowing inflammation to heal, or because pollens do not reach the lower airways or because they are less damaging to the airways. In many reviews and guidelines allergens are stated as causing or worsening asthma, and the allergens listed are pollens, animals, HDM, cockroaches, and moulds-usually in that order. However, in terms of secondary prevention it is clear that exposure to HDM and cat are more easily controlled than exposure to moulds and pollens. ${ }^{27}$

The severity of asthma in terms of symptoms and airway hyperresponsiveness is determined by the increased ability of the airways to narrow excessively. This may in part be due to the degree of inflammation, especially inflammation in the adventitial layer of the airway, which theoretically uncouples the airway smooth muscle from the local elastic recoil and thus the effects of stretch. ${ }^{28}$ However, other factors may be important. There is some evidence that serum IgE affects the behaviour of the airway smooth muscle in animal studies and Sunyer $e a^{29}$ showed that total IgE was important. However, it is important to recognise that not all allergic people get asthma, and it seems likely that there are a number of genetic and environmental factors that predispose the airway smooth muscle to behave abnormally in the presence of mediators from the allergic inflammatory process. The possibilities that are now emerging include the polymorphism of the beta receptor, ${ }^{30}$ the amount of myosin light chain kinase, ${ }^{31}$ and other inflammatory stimuli such as ozone, ${ }^{32}$ endotoxin, ${ }^{33}$ and the home environment. ${ }^{34}$

Until we understand the nature of asthma, it will not be possible to determine severity accurately. However, increasing severity is likely to be associated with skin test sensitivity to HDM and Alternaria ${ }^{35}$ and, in the absence of parasites, the total IgE level is a likely measure of severity. ${ }^{29}$ Onset at a young age ( $<5$ years) and a strong family history will also increase the likelihood of severe disease.${ }^{13}$ On the other hand, a patient with hayfever and allergy restricted to pollens, particularly rye, birch and ragweed, who has asthmatic symptoms in spring probably has intermittent asthma. ${ }^{1}$

Perhaps a different approach is needed and, rather than defining severity, we should concentrate on the degree of abnormality of the behaviour of the airway smooth muscle. The greater the degree of airway hyperresponsiveness, the more the patient needs to be treated with inhaled corticosteroids (starting with a high dose and reducing to the lowest dose that keeps control); in some patients this may mean intermittent treatment with inhaled corticosteroids. The intensity of the treatment may well be different in someone with HDM sensitivity compared with someone with sensitivity to pollen only. The aim of management for all asthmatics is fewer exacerbations and no decline in lung function with time. In addition, in those with well established disease we do not know if the long term outcome can be improved by constant treatment, because so far there have been no long term trials of the outcome of different treatments on large populations.

Correspondence to: Professor A J Woolcock.

A J WOOLCOCK

Institute of Respiratory Medicine,

University of Sydney,

Australia

D DUSSER

I FAJAC

Service de Pneumologie,

UFR Cochin-Port-Royal,

Université René,

Paris, France 
1 Global initiative for asthma. Global strategy for asthma management and prevention. NHLBI/WHO Workshop Report, March 1993. National Institutes of

2 British Thoracic Society. The British guidelines on asthma management 1995: review and position statement. Thorax 1997;52(Suppl 1):S1-S21.

3 Ellman MS, Viscoli CM, Sears MR, et al. A new index of prognostic severity for chronic asthma. Chest 1997;112:582-90.

4 Gautier V, Redier H, Pujol JL, et al. Comparison of an expert system with other clinical scores for the evaluation of severity of asthma. Eur Respir $\mathcal{F}$ 1996;9:58-64.

5 Reddel HK, Trevillion LM, Salome CM, et al. A scoring system for mild to severe asthma. Eur Respir $\mathcal{F}$ 1995;8(Suppl 19):489S.

6 Cho SH, Seo JY, Choi DC, et al. Pathological changes according to the severity of asthma. Clin Exp Allergy 1996;26:1210-9.

7 Synek M, Beasley R, Frew AJ, et al. Cellular infiltration of the airways in asthma of varying severity. Am $\mathcal{F}$ Respir Crit Care Med 1996;154:224-30.

8 Roisman GL, Lacronique JG, Desmazes-Dufeu N, et al. Airway responsiveness to bradykinin is related to eosinophilic inflammation in asthma. $A m \mathcal{F}$ ness to bradykinin is related to eosinop

9 Ryan G, Latimer KM, Dolovich J, et al. Bronchial responsiveness to histamine: relationship to diurnal variation of peak flow rate, improvement histamine: relationship to diurnal variation of peak flow rate, impro

10 National asthma education and prevention program. Clinical practice guidelines. Expert Panel Report 2. Guidelines for the diagnosis and management of asthma. National Institutes of Health. National Heart, Lung and Blood Institute, 1997

11 Peat JK. Asthma: longitudinal prospective. F Asthma 1998;35:237-43.

12 Burney PGJ, Luczynska S, Jarvis CD. The European community respiratory health survey. Eur Respir f 1994;7:954-60.

13 Peat JK, Salome CM, Woolcock AJ. Longitudinal changes in atopy during a 4-year period: relation to bronchial hyperresponsiveness and respiratory symptoms in a population sample of Australian schoolchildren. F Allergy Clin Immunol 1990;85:65-74.

14 Peat JK, Tovey E, Toelle BG, et al. House dust mite allergens. A major risk factor for childhood asthma in Australia. Am f Respir Crit Care Med 1996; 153:141-6.

15 Platts-Mills TA. Allergens and asthma. Allergy Proc 1990;11:269-71.

16 Custovic A, Taggart SCO, Francis HC, et al. Exposure to house dust mite allergens and the clinical activity of asthma. F Allergy Clin Immunol allergens and

17 Peat JK, Toelle B, Salome CM, et al. Predictive nature of bronchial responsiveness and respiratory symptoms in a one year cohort study of Sydney siveness and respiratory symptoms in a o

18 Sears MR, Burrows B, Flannery EM, et al. Atopy in childhood. 1. Gender and allergen related risks for development of hay fever and asthma. Clin Exp Allergy 1993;23:941-8.

19 Platts-Mills TAE, Squillace SP. Allergen sensitization and perennial asthma. Int Arch Allergy Immunol 1997;113:83-6.
20 Eiser N, Kerrebijn K, Quanjer P. SEPCR working group "bronchial hyperreactivity": guidelines for standardization of bronchial challenges with (nonspecific) bronchoconstricting agents. Bull Eur Physiopathol Respir 1983;19:495-514.

21 Letrait M, Lurie A, Bean K, et al. The asthma impact record (AIR) index: a rating scale to evaluate the quality of life of asthmatic patients in France. Eur Respir F 1996;9:1167-73.

22 Peat JK, Woolcock AJ. Sensitivity to common allergens: relation to respiratory symptoms and bronchial hyperresponsiveness in children from three different climatic areas of Australia. Clin Exp Allergy 1991;21:573-81.

23 Prieto JL, Gutierrez V, Berto JM, et al. Sensitivity and maximal response to methacholine in perennial and seasonal allergic rhinitis. Clin Exp Allergy 1996;26:61-7.

24 Chinn S, Jarvis D, Luczynska CM, et al. Measuring atopy in a multi-centre epidemiological study. Eur F Epidemiol 1996;12:155-62.

25 Jarvis D. The association of age, gender and smoking with total IgE and specific IgE: results from the European community respiratory health survey (ECRHS). Eur Respir f 1997;10(Suppl 25):175

26 Soriano JB, Tobias A, Kogevinas M, et al. Atopy and nonspecific bronchial responsiveness. A population-based assessment. The Spanish Group of the European Community Respiratory Health Survey. Am f Respir Crit Care Med 1996;154:1636-40.

27 Peat JK. Prevention of asthma. Eur Respir ₹ 1996;9:1545-55.

28 Macklem PT. A theoretical analysis of the effect of airway smooth muscle load on airway narrowing. Am ₹ Respir Crit Care Med 1996;153:83-9.

29 Sunyer J, Anto JM, Castellsague J, et al. Total serum IgE is associated with asthma independently of specific IgE levels. The Spanish Group of the European Study of Asthma. Eur Respir F 1996;9:1880-4.

30 Reihsaus E, Innis M, MacIntyre N, et al. Mutations in the gene encoding for the beta 2-adrenergic receptor in normal and asthmatic subjects. Am f Respir Cell Mol Biol 1993;8:334-9.

31 Ouksel H, Viires N, Pavlovic D, et al. MLCK and SERCA expression in tracheal and smooth muscle from sensitised guinea pigs. Eur Respir 7 1997;10(Suppl 25):291.

32 Delfino RJ, Coate BD, Zeiger RS, et al. Daily asthma severity in relation to personal ozone exposure and outdoor fungal spores. Am $\mathcal{F}$ Respir Crit Care Med 1996;154(3 pt 1):633-41.

33 Michel O, Kips J, Duchateau J, et al. Severity of asthma is related to endotoxin in house dust. Am f Respir Crit Care Med 1996;154:1641-6.

34 Strachan DP, Carey IM. Home environment and severe asthma in adolescence: a population based case-control study. BMF 1995;311:1053-

35 Gray EJ, Peat JK, Mellis CM, et al. Asthma severity and morbidity in a population sample of Sydney schoolchildren. Part 1: prevalence and effect of air pollutants in coastal regions. Aust NZ F Med 1994;24:168-75. 